\begin{tabular}{|c|c|c|}
\hline $\begin{array}{c}\text { RESEARCH } \\
\text { ArtiCLE }\end{array}$ & \multicolumn{2}{|c|}{ Volume 9 | Issue 1 | June, 2018 | 79-82 — e ISSN-2231-6418 } \\
\hline $0=$ & DOI: 10.15740/HAS/ARJSS/9.1/79-82 & Visit us : www.researchjournal.c \\
\hline
\end{tabular}

\title{
Determine the relationship of self - esteem and depression
}

Sunita and Pinki Rani*

Department of Human Development and Family Studies, College of Home Science, C.C.S. Haryana Agricultural University, Hisar (Haryana) India

\section{ARTICLE INFO :}

$\begin{array}{lll}\text { Received } & : & 09.02 .2018 \\ \text { Revised } & : & 05.05 .2018 \\ \text { Accepted } & : & 20.05 .2018\end{array}$

\section{KEY WORDS :}

Adolescents, Depression, Communication, Experience, Life challenge

HOW TO CITE THIS ARTICLE :

Sunita and Rani, Pinki (2018). Determine the relationship of self - esteem and depression. Adv. Res. J. Soc. Sci., 9 (1) : 79-82, DOI: 10.15740/HAS/ARJSS/9.1/ 79-82.

Copyright@2018 : Hind Agri -

Horticultural Society

*Author for correspondence

\begin{abstract}
Self-esteem as the experience of capable of meeting life challenge and being worthy of happiness. Depression among adolescents has emerged as a major mental health problem. Depression and self-esteem are intertwined and contribute to negative effects. The study was conducted in Hisar district of Haryana state. All the adolescents studying in $9^{\text {th }}$ and $10^{\text {th }}$ standard falling in the age group $15-16$ years were included in the sample for the study. Self-esteem was taken as dependent variable. Self-Esteem was assessed by Rosenberg's Self-Esteem Scale (RSES) by Rosenberg's (1989). Depression was taken as independent variables. Beck's Depression Inventory (BDI) by Beck $e t$ al. (1988) was used to assess the depression. Result revealed that comparatively higher percentage of males than the females reported moderate to severe depression symptoms. Result further reflects that negative and significant correlation between depression and self-esteem $(r=-0.25)$. This means that adolescents who had high depression reported less self-esteem.
\end{abstract}

